\title{
Rate and Timing Effects of Growth Regulating Herbicides Applications on Grain Sorghum (Sorghum bicolor) Growth and Yield
}

\author{
Thierry E. Besançon, ${ }^{1}$ Ranjit Riar, ${ }^{2}$ Ronnie W. Heiniger, ${ }^{3}$ \\ Randy Weisz, ${ }^{3}$ and Wesley J. Everman ${ }^{3}$ \\ ${ }^{1}$ Department of Plant Biology \& Pathology, Rutgers University, New Brunswick, NJ 08901, USA \\ ${ }^{2}$ Agriculture \& Natural Resources Department, University of Minnesota, Crookston, MN 56716, USA \\ ${ }^{3}$ Department of Crop \& Soil Sciences, North Carolina State University, Raleigh, NC 27695, USA
}

Correspondence should be addressed to Wesley J. Everman; wes_everman@ncsu.edu

Received 24 March 2016; Accepted 7 August 2016

Academic Editor: Mumtaz Cheema

Copyright (C) 2016 Thierry E. Besançon et al. This is an open access article distributed under the Creative Commons Attribution License, which permits unrestricted use, distribution, and reproduction in any medium, provided the original work is properly cited.

\begin{abstract}
Dicamba and 2,4-D are among the most common and inexpensive herbicides used to control broadleaf weeds. However, different studies have pointed the risk of crop injury and grain sorghum yield reduction with postemergence applications of 2,4-D. No research data on grain sorghum response to 2,4-D or dicamba exists in the Southeastern United States. Consequently, a study was conducted to investigate crop growth and yield response to $2,4-\mathrm{D}\left(100,220\right.$, and $330 \mathrm{~g}$ acid equivalent ha $\left.{ }^{-1}\right)$ and dicamba $(280 \mathrm{~g}$ acid equivalent $\mathrm{ha}^{-1}$ ) applied on 20 to $65 \mathrm{~cm}$ tall sorghum. Greater stunting resulted from 2,4-D applied at $330 \mathrm{~g}$ acid equivalent ha ${ }^{-1}$ or below $45 \mathrm{~cm}$ tall sorghum whereas lodging prevailed with 2,4-D at $330 \mathrm{~g}$ acid equivalent $\mathrm{ha}^{-1}$ and dicamba applied beyond $35 \mathrm{~cm}$ tall crop. Regardless of local environmental conditions, 2,4-D applied up to $35 \mathrm{~cm}$ tall did not negatively impact grain yield. There was a trend for yields to be somewhat lower when 2,4-D was applied on 45 or $55 \mathrm{~cm}$ tall sorghum whereas application on $65 \mathrm{~cm}$ tall sorghum systematically decreased yields. More caution should be taken with dicamba since yield reduction has been reported as early as applications made on $35 \mathrm{~cm}$ tall sorghum for a potentially dicamba sensitive cultivar.
\end{abstract}

\section{Introduction}

Grain sorghum [Sorghum bicolor (L.) Moench], a major cereal crop grown in the United States, recently gained renewed interest in the southeastern region where it is used primarily as an animal feedstock. In 2012, 20,000 ha of grain sorghum was grown in North Carolina, an estimated 10-fold increase over 2011 [1]. Weed control remains a major challenge for sorghum producers worldwide as the percentage of grain sorghum yield lost due to weed competition exceeds that of most other grain crops [2]. Herbicide options for postemergence applications (POST) are more restricted in grain sorghum than for other major row crops because the sorghum worldwide market is not large enough to justify the development and registration of new herbicides [2]. Additionally, several products that used POST in sorghum have long rotation restrictions on their label that can limit their use in diverse cropping environments [3]. Among the POST herbicides available for controlling broadleaf weeds in grain sorghum, 2,4-D and dicamba are phenoxy and benzoic acid herbicides, respectively, that provide excellent control if applied while weed seedlings are young [4]. Furthermore, rotation to a non-glyphosate-resistant crop such as grain sorghum and the subsequent use of growth regulating herbicides is a recommended practice to improve control and prevent the spread of herbicide-resistance among several species of broadleaf weeds [5].

While 2,4-D is a good option for weed control in grain sorghum, crop injury in the form of rolled leaves and brittle, spreading stems, and tillers may result from its application on grain sorghum [6]. Previous studies have shown that 2,4$\mathrm{D}$ can cause a shortening of developing roots and shoots from sorghum seeds germinated on Petri dishes [7]. Sorghum sprayed with 2,4-D at $225 \mathrm{~g}$ acid equivalent (ae) $\mathrm{ha}^{-1}$ when 
plant height was 15 to $20 \mathrm{~cm}$ presented chromosomal aberrations within the pollen mother cells, mostly aneuploidy and polyploidy [8].

Grain sorghum tolerance to 2,4-D may also differ among sorghum varieties. In a study comparing the competitiveness and herbicide tolerance of ten sorghum hybrids in Nebraska, 2,4-D applied at $1100 \mathrm{~g} \mathrm{ae} \mathrm{ha}^{-1}$ caused important sorghum injury by damaging roots, lodging, and abnormal growth independently of the cultivars. Most of the varieties recovered and yielded similarly to a weed-free check, except three that presented a significant yield decrease ranging from 12 to $27 \%$ [9]. Herbicide formulation also plays a role in the grain sorghum tolerance to 2,4-D. Low-volatile ester formulation provided better redroot pigweed control than amine salt but resulted in higher percentage of grain sorghum injury without impacting the yield [10].

Recent studies have shown that grain sorghum productivity and lodging are sensitive to the rate of 2,4-D as well as phenological stage at which $2,4-\mathrm{D}$ is applied. In a greenhouse experiment conducted in Brazil, Dan et al. [11] reported higher percentage of foliage injury with 2,4-D application made at the three-leaf stage rather than at the nine-leaf stage, regardless of 2,4-D rate ranging from 0 to $1,608 \mathrm{~g} \mathrm{ae} \mathrm{ha}^{-1}$. Yet, lodging was significantly more important when 2,4-D was applied at the nine-leaf stage compared to the three-leaf stage, with over $40 \%$ and $<10 \%$ lodged plants, respectively, for 2,4$\mathrm{D}$ rate exceeding $840 \mathrm{~g} \mathrm{ae} \mathrm{ha}^{-1}$. Yield reduction ranging from 20 to $38 \%$ occurred for $2,4-\mathrm{D}$ applied at the nine-leaf stage whereas loss did not exceed $25 \%$ for $1,608 \mathrm{~g}$ ae ha $^{-1} 2,4-\mathrm{D}$ applied at the three-leaf stage [11]. Increasing rates of 2,4$\mathrm{D}$ caused a linear reduction in plant height, biomass, and green dry matter accumulation as well as decreased yield, especially at rates above $1,000 \mathrm{~g} \mathrm{ae} \mathrm{ha}^{-1}$ and late applications [12]. In similar research, 2,4-D applied at the recommended rate $\left(720 \mathrm{~g} \mathrm{ae} \mathrm{ha}^{-1}\right)$ and $1.5 \mathrm{x}$ dosage at the five-leaf and eightleaf stages has been reported to cause significant toxicity from 12 to $24 \%$ and reduce grain yield from 12 to $16 \%$ because of a decrease in the number of grains per panicle [13]. When compared to $2,4-\mathrm{D}$ applied at 225 or $720 \mathrm{~g}$ ae ha $^{-1}$, dicamba at $144 \mathrm{~g}$ ae ha $^{-1}$ resulted in similar weed control but with less damage to sorghum and without reducing yield [14].

Previous studies have shown dicamba injury on sensitive wheat (Triticum aestivum L.) varieties. Schroeder and Banks [15] reported crop injury and yield reduction when dicamba was applied at the midtillering stage on soft red winter wheat planted 10 or 21 days later than recommended. Schweizer et al. [16] found that sorghum yield was significantly reduced when a mixture of $280 \mathrm{~g} \mathrm{a} \mathrm{ha}^{-1}$ of dicamba and $560 \mathrm{~g} \mathrm{ae} \mathrm{ha}^{-1}$ of 2,4-D was applied twice at the same rate in spring. Walker et al. [17] reported dicamba phytotoxicity on grain sorghum when leached into the soil but not when remaining on the soil surface. Dicamba applied at 280 or $560 \mathrm{~g}$ ae ha ${ }^{-1}$ one day before sowing significantly reduced sorghum seedling growth if $25 \mathrm{~mm}$ of irrigation was received within four days of sowing and yield if $144 \mathrm{~mm}$ of rainfall was received within 14 days of sowing.

These results stress the need for assessing the potential damage of synthetic auxins applied POST over-the-top beyond the current sorghum height recommendation of $20 \mathrm{~cm}[18,19]$. Therefore, the objectives of this study were to determine the effect of 2,4-D and dicamba applied at different rates and phenological stages under different soil types and environmental conditions on grain sorghum growth, lodging, and yield.

\section{Materials and Methods}

Field experiments were conducted at the Upper Coastal Plain Research Station near Rocky Mount, NC, in 2012, 2013, and 2014, the Central Crops Research Station, Clayton, NC, in 2012 and 2013, and the Caswell Research Farm near Kinston, NC, in 2014 resulting in six year-by-location combinations (hereafter referred as to environments). All experiments were conducted under dryland conditions. Soils were a Roanoke loam (fine, mixed, semiactive, thermic Typic Endoaquults) with $2.3 \%$ organic matter and $\mathrm{pH} 6.4$ in 2012 and 2013 and a Wickham sandy loam (fine-loamy, mixed, semiactive, thermic Typic Hapludults) associated with an AltaVista fine sandy loam (fine-loamy, mixed, semiactive, thermic Aquic Hapludults) with $1.3 \%$ organic matter and pH 5.7 in 2014 at Rocky Mount, Varina loamy sand (fine, kaolinitic, thermic Plinthic Paleudults) with $2.4 \%$ organic matter and $\mathrm{pH} 6$ at Clayton, and Woodington loamy sand (coarse-loamy, siliceous, semiactive, thermic Typic Paleaquults) with 1.9\% organic matter and $\mathrm{pH} 6.1$ at Kinston.

Sorghum hybrid DeKalb DKS 53-67 (Monsanto, Saint Louis, MO) was seeded at a rate of 296,000 seeds ha ${ }^{-1}$ at Rocky Mount and Kinston. At Clayton, sorghum cultivars Mycogen1G600 (Dow AgroSciences, Indianapolis, IN) and Pioneer 84P80 (DuPont, Johnston, IA) were seeded at a rate of 247,000 seeds ha $^{-1}$ in 2012 and 2013, respectively. Fields were disk tilled before seeding at each environment and seeds were planted in $38 \mathrm{~cm}$ rows at a depth of $1.9 \mathrm{~cm}$ (see Table 1 for planting dates). S-Metolachlor [2-chloro-N-(2-ethyl-6-methylphenyl)-N-(1-methoxypropan-2-yl)acetamide] and atrazine [6-chloro-N2-ethyl-N4-(propan-2-yl)-1,3,5-triazine-2,4diamine] herbicides (Bicep II Magnum ${ }^{\circledR} 15 G$, Syngenta Crop Protection, Greensboro, NC) were applied before emergence at 1412 and $1824 \mathrm{~g}$ active ingredient ha ${ }^{-1}$, respectively. Standard fertilization and insect management practices as recommended by the North Carolina Cooperative Extension Service were followed.

The experimental design at each environment was a two-factorial arrangement in a randomized complete block with four replications. A weed-free control that did not receive POST application was added within each replication to serve as a comparison basis during the ratings. Plot size was 2.4 wide by $9.1 \mathrm{~m}$ long, with row spacing of $38 \mathrm{~cm}$. Factors including synthetic auxins applied POST at different rates and timings. Herbicide treatments consisted of dimethylamine formulated 2,4-D [2-(2,4-dichlorophenoxy) acetic acid] (Weedar $64^{\circledR}$, Nufarm, Burr Ridge, IL) at 100, 220, and $330 \mathrm{gaeha}^{-1}$ and dicamba [3,6-dichloro-2methoxybenzoic acid] (Clarity ${ }^{\circledR}$, BASF, Research Triangle Park, NC) at $280 \mathrm{~g} \mathrm{ae} \mathrm{ha}^{-1}$. POST treatments were applied when grain sorghum was approximately $35,45,55$, or $65 \mathrm{~cm}$ tall. An additional application on $20 \mathrm{~cm}$ tall sorghum was 
TABLE 1: Planting and herbicide application dates.

\begin{tabular}{|c|c|c|c|c|c|c|c|c|c|}
\hline \multirow{3}{*}{ Location } & \multirow{3}{*}{ Year } & \multirow{3}{*}{ Planting } & \multicolumn{6}{|c|}{ Herbicide application } & \multirow{3}{*}{ Harvest } \\
\hline & & & \multirow{2}{*}{ PRE } & \multicolumn{5}{|c|}{ POST } & \\
\hline & & & & $20 \mathrm{~cm}$ & $35 \mathrm{~cm}$ & $45 \mathrm{~cm}$ & $55 \mathrm{~cm}$ & $65 \mathrm{~cm}$ & \\
\hline \multirow{3}{*}{ Rocky Mount } & 2012 & $06 / 25$ & $06 / 25$ & - & $07 / 13$ & $07 / 19$ & $07 / 24$ & $07 / 27$ & $11 / 14$ \\
\hline & 2013 & $06 / 14$ & $06 / 14$ & - & $07 / 22$ & $07 / 25$ & $08 / 1$ & $08 / 5$ & $11 / 3$ \\
\hline & 2014 & $06 / 30$ & $05 / 30$ & $06 / 17$ & $06 / 24$ & $06 / 27$ & $07 / 3$ & $07 / 11$ & $09 / 23$ \\
\hline \multirow{2}{*}{ Clayton } & 2012 & $06 / 26$ & $06 / 26$ & - & $07 / 20$ & $07 / 24$ & $07 / 30$ & $08 / 6$ & $11 / 13$ \\
\hline & 2013 & $06 / 28$ & $06 / 26$ & - & $08 / 7$ & $08 / 12$ & $08 / 20$ & $08 / 23$ & $11 / 14$ \\
\hline Kinston & 2014 & $05 / 27$ & $05 / 27$ & $06 / 14$ & $06 / 23$ & $06 / 29$ & $07 / 7$ & $07 / 14$ & $10 / 7$ \\
\hline
\end{tabular}

Abbreviation: PRE, preemergence; POST, postemergence.

added in 2014. No surfactant was added to POST treatments. In all years, the PRE and POST herbicides were applied in water with a $\mathrm{CO}_{2}$-pressurized backpack sprayer equipped with flat-fan nozzles XR1102 (TeeJet, Wheaton, IL) delivering $140 \mathrm{~L} \mathrm{ha}^{-1}$ at $165 \mathrm{kPa}$ (see Table 1 for applications dates).

For each environment, grain sorghum height at boot stage as well as grain yield at harvest was recorded. Plots were machine harvested between mid-October and midNovember using a combine (Model Delta, Wintersteiger, Ried, Austria) specifically adapted for harvesting small plots and crop weights were adjusted to $14 \%$ moisture. In 2014, at Rocky Mount and Kinston, visual grain sorghum injury (chlorosis and stunting) and lodging were evaluated following synthetic auxins applications. Injury symptoms were only recorded in the form of stunting; no leaf chlorosis or necrosis was observed at both locations. These observations were based on a scale of 0 (no chlorosis, stunting, or lodging) to 100 (complete plant death or lodging) and recorded approximately 7,21, and 35 days after application (DAA) as well as at harvest. Only injury in the form of stunting was observed at both locations and is therefore reported. Ratings taken before harvest did not show any stunting injury and are therefore not reported.

Grain sorghum stunting and lodging data were analyzed as a two-way analysis of variance (ANOVA) using the PROC GLIMMIX procedure of SAS (version 9.4; SAS Institute Inc., Cary, NC). As stunting and lodging ratings were taken relatively to the weed-free control, this one was not included in the analysis. Data were transformed to the arcsine square root prior to ANOVA to stabilize the variances [20]. Because the transformation of the data did not change the separation of means, only nontransformed data are presented. The interaction between location and herbicide rate or application timing was not statistically significant for sorghum stunting and lodging. However, interaction between herbicide rate and application timing was significant $(P \leq 0.05)$. Thus, data were analyzed and are presented by herbicide rates within each application timing or by application timings within each herbicide rate.

Data for sorghum height at boot stage and grain yield at harvest were firstly subjected to a one-way ANOVA using the PROC GLIMMIX procedure of SAS (version 9.4; SAS Institute Inc., Cary, NC) and Fisher's protected LSD test to separate treatments means $(P \leq 0.05)$. The environment-by-treatments interaction was statistically significant for sorghum height at boot stage as well as grain yield at harvest; therefore, data are reported by environment. Subsequently, the dicamba treatment was dropped to separately analyze the effect of $2,4-\mathrm{D}$ rates on grain sorghum yield and date were subjected to a one-way ANOVA using PROC GLIMMIX and Fisher's protected LSD test to separate treatments means $(P \leq 0.05)$. In the absence of environment-by-treatments interaction, 2,4-D treatments have been pooled over environments.

\section{Results and Discussion}

3.1. Crop Stunting and Lodging. Stunting was principally observed 7 and 21DAA, with stunting becoming transient by 35 DAA. Sorghum stunting 7 and 21 DAA increased with higher rate of 2,4-D applied on 20 to $45 \mathrm{~cm}$ tall sorghum, ranging from 2 to $12 \% 7 \mathrm{DAA}$ and from 0 to $7 \% 21 \mathrm{DAA}$ with 2,4-D at 100 and $330 \mathrm{~g}$ ae ha $^{-1}$, respectively (Table 2). No or minimal stunting $(\leq 2 \%)$ regardless of 2,4 -D rates was noted at 7 and 21 DAA with applications on sorghum taller than $45 \mathrm{~cm}$. At 35 DAA, negligible stunting $(\leq 2 \%)$ was only observed with 2,4-D applied at $330 \mathrm{gaeha}^{-1}$ on 20 or $32 \mathrm{~cm}$ tall sorghum. At 7 DAA and for any application timing, dicamba applied at $280 \mathrm{~g}$ ae ha $^{-1}$ resulted in a higher percentage of stunting ranging from 3 to $17 \%$ than the highest rate of 2,4$\mathrm{D}$ at $330 \mathrm{~g}$ ae ha $^{-1}$. Similar result was observed $21 \mathrm{DAA}$ for dicamba applied on 45 to 65 tall sorghum with stunting ranging from 1 to $4 \%$. Regardless of time of application, limited stunting $(\leq 2 \%)$ was noted $35 \mathrm{DAA}$ for dicamba at $280 \mathrm{~g} \mathrm{ae} \mathrm{ha}^{-1}$.

2,4-D applied at $100 \mathrm{~g}$ ae ha $^{-1}$ caused no or $\leq 3 \%$ stunting 7 DAA with greater injury recorded for 20 to $45 \mathrm{~cm}$ tall sorghum at time of application (Table 3 ). Increasing 2,4-D rate to 220 or $330 \mathrm{~g} \mathrm{ae} \mathrm{ha}^{-1}$ caused between $8 \%$ stunting and $12 \%$ stunting 7 DAA when sorghum was 20 to $35 \mathrm{~cm}$ tall at time of application. At $21 \mathrm{DAA}, \geq 5 \%$ stunting was only detected for 2,4-D at $330 \mathrm{~g} \mathrm{ae} \mathrm{ha}^{-1}$ applied on 20 to $35 \mathrm{~cm}$ tall sorghum. No or $\leq 3 \%$ stunting was observed 21 and 35 DAA with $2,4-\mathrm{D}$ at 100 or $220 \mathrm{~g}$ ae ha ${ }^{-1}$ regardless of time of application or with 2,4-D at $330 \mathrm{~g}$ ae ha $^{-1}$ applied beyond $35 \mathrm{~cm}$ sorghum height. Similar results have been reported by Dan et al. [11] who observed that 2,4-D applications during 
TABLE 2: Stunting from POST applications of 2,4-D and dicamba as affected by application timing in 2014 at Rocky Mount and Kinston, North Carolina.

\begin{tabular}{|c|c|c|c|c|}
\hline \multirow{3}{*}{$\begin{array}{l}\text { Application } \\
\text { timing } \\
\mathrm{cm}\end{array}$} & \multirow{3}{*}{$\begin{array}{l}\text { Herbicide } \\
\text { g ae ha }^{-1}\end{array}$} & \multicolumn{3}{|c|}{ Stunting $^{1,2}$} \\
\hline & & $7 \mathrm{DAA}$ & $21 \mathrm{DAA}$ & $35 \mathrm{DAA}$ \\
\hline & & & $\%$ & \\
\hline \multirow{4}{*}{20} & 2,4-D 100 & $2^{c}$ & $0^{c}$ & $0^{\mathrm{a}}$ \\
\hline & 2,4-D 220 & $7^{\mathrm{b}}$ & $1^{c}$ & $0^{\mathrm{a}}$ \\
\hline & 2,4-D 330 & $11^{\mathrm{ab}}$ & $5^{\mathrm{a}}$ & $1^{\mathrm{a}}$ \\
\hline & Dicamba & $12^{\mathrm{a}}$ & $3^{\mathrm{b}}$ & $0^{\mathrm{a}}$ \\
\hline \multirow{4}{*}{32} & 2,4-D 100 & $3^{\mathrm{d}}$ & $0^{c}$ & $0^{\mathrm{b}}$ \\
\hline & $2,4-\mathrm{D} 220$ & $8^{c}$ & $3^{\mathrm{b}}$ & $0^{\mathrm{b}}$ \\
\hline & 2,4-D 330 & $12^{\mathrm{b}}$ & $7^{\mathrm{a}}$ & $2^{\mathrm{a}}$ \\
\hline & Dicamba & $17^{\mathrm{a}}$ & $7^{\mathrm{a}}$ & $2^{\mathrm{a}}$ \\
\hline \multirow{4}{*}{45} & 2,4-D 100 & $2^{c}$ & $0^{\mathrm{b}}$ & $0^{\mathrm{b}}$ \\
\hline & 2,4-D 220 & $2^{c}$ & $1^{\mathrm{b}}$ & $0^{\mathrm{b}}$ \\
\hline & 2,4-D 330 & $6^{\mathrm{b}}$ & $2^{\mathrm{ab}}$ & $0^{\mathrm{b}}$ \\
\hline & Dicamba & $10^{\mathrm{a}}$ & $4^{\mathrm{a}}$ & $2^{\mathrm{a}}$ \\
\hline \multirow{4}{*}{55} & $2,4-\mathrm{D} 100$ & $0^{\mathrm{b}}$ & $0^{\mathrm{b}}$ & $0^{\mathrm{a}}$ \\
\hline & 2,4-D 220 & $0^{\mathrm{b}}$ & $0^{\mathrm{b}}$ & $0^{\mathrm{a}}$ \\
\hline & 2,4-D 330 & $2^{\mathrm{a}}$ & $0^{\mathrm{b}}$ & $0^{\mathrm{a}}$ \\
\hline & Dicamba & $5^{\mathrm{a}}$ & $2^{\mathrm{a}}$ & $1^{\mathrm{a}}$ \\
\hline \multirow{4}{*}{65} & 2,4-D 100 & $0^{\mathrm{b}}$ & $0^{\mathrm{a}}$ & $0^{\mathrm{a}}$ \\
\hline & $2,4-\mathrm{D} 220$ & $0^{\mathrm{b}}$ & $0^{\mathrm{a}}$ & $0^{\mathrm{a}}$ \\
\hline & 2,4-D 330 & $0^{\mathrm{b}}$ & $0^{\mathrm{a}}$ & $0^{\mathrm{a}}$ \\
\hline & Dicamba & $3^{\mathrm{a}}$ & $1^{\mathrm{a}}$ & $0^{\mathrm{a}}$ \\
\hline
\end{tabular}

${ }^{1}$ Means within a column followed by the same letters are not different according to Fisher's protected LSD test at $P \leq 0.05$.

${ }^{2}$ Abbreviation: DAA, days after application.

the early development stages of sorghum (up to six fully expanded leaves) resulted in the highest levels of toxicity when the rates of 2,4-D exceeded $210 \mathrm{~g}$ ae ha ${ }^{-1}$. Persistence of sorghum injury has also been previously documented up to $40 \mathrm{DAA}$ with $16 \%$ injury when $2,4-\mathrm{D}$ at $720 \mathrm{~g} \mathrm{ae} \mathrm{ha}^{-1}$ was applied at the five fully expanded leaves stage and $20 \%$ when applied at the eight fully expanded leaves stage [14].

Independently of the sorghum growth stage at which POST was applied, raising the 2,4-D rate from 100 to $330 \mathrm{~g} \mathrm{ae} \mathrm{ha}^{-1}$ increased the percentage of lodged plants by 2 to $4 \% 21 \mathrm{DAA}$ and by 4 to $14 \% 35 \mathrm{DAA}$ (Table 4 ). Application of 2,4-D beyond $35 \mathrm{~cm}$ sorghum height caused significant higher lodging at harvest for $330 \mathrm{gaeha}^{-1}$ compared to 100 and $220 \mathrm{gaeha}^{-1}$ with 6 to $7 \%$ and $\leq 2 \%$, respectively. Depending on the time of application, dicamba applied at the labelled field rate for sorghum $\left(280 \mathrm{~g} \mathrm{ae} \mathrm{ha}^{-1}\right)$ caused lodging between 3 and 13\% $21 \mathrm{DAA}$ and 7 to 25\% 35 DAA, similar results to those noted for 2,4-D applied at the highest rate $\left(330 \mathrm{~g} \mathrm{ae} \mathrm{ha}^{-1}\right)$.

Our data also show that grain sorghum is more sensitive to lodging resulting from growth regulating herbicides applied at later sorghum stages (Table 5). None or minimal lodging $(\leq 10 \%)$ was observed at 7,21 , and $35 \mathrm{DAA}$ or at
TABLE 3: Stunting from POST applications of 2,4-D and dicamba as affected by herbicide rate in 2014 at Rocky Mount and Kinston, North Carolina.

\begin{tabular}{|c|c|c|c|c|}
\hline \multirow{3}{*}{$\begin{array}{l}\text { Herbicide } \\
\text { g ae ha }^{-1}\end{array}$} & \multirow{3}{*}{$\begin{array}{l}\text { Application } \\
\text { timing } \\
\mathrm{cm}\end{array}$} & \multicolumn{3}{|c|}{ Stunting $^{1,2}$} \\
\hline & & $7 \mathrm{DAA}$ & $21 \mathrm{DAA}$ & $35 \mathrm{DAA}$ \\
\hline & & & $\%$ & \\
\hline \multirow{5}{*}{ 2,4-D 100} & 20 & $2^{\mathrm{a}}$ & $0^{\mathrm{a}}$ & $0^{\mathrm{a}}$ \\
\hline & 35 & $3^{\mathrm{a}}$ & $0^{\mathrm{a}}$ & $0^{\mathrm{a}}$ \\
\hline & 45 & $2^{\mathrm{a}}$ & $0^{\mathrm{a}}$ & $0^{\mathrm{a}}$ \\
\hline & 55 & $0^{\mathrm{b}}$ & $0^{\mathrm{a}}$ & $0^{\mathrm{a}}$ \\
\hline & 65 & $0^{\mathrm{b}}$ & $0^{\mathrm{a}}$ & $0^{\mathrm{a}}$ \\
\hline \multirow{5}{*}{ 2,4-D 220} & 20 & $7^{\mathrm{a}}$ & $1^{\mathrm{a}}$ & $0^{\mathrm{a}}$ \\
\hline & 35 & $8^{\mathrm{a}}$ & $3^{\mathrm{a}}$ & $0^{\mathrm{a}}$ \\
\hline & 45 & $2^{\mathrm{b}}$ & $1^{\mathrm{b}}$ & $0^{\mathrm{a}}$ \\
\hline & 55 & $0^{\mathrm{b}}$ & $0^{\mathrm{b}}$ & $0^{\mathrm{a}}$ \\
\hline & 65 & $0^{\mathrm{b}}$ & $0^{\mathrm{b}}$ & $0^{\mathrm{a}}$ \\
\hline \multirow{5}{*}{ 2,4-D 330} & 20 & $11^{\mathrm{a}}$ & $5^{\mathrm{a}}$ & $1^{\mathrm{a}}$ \\
\hline & 35 & $12^{\mathrm{a}}$ & $7^{\mathrm{a}}$ & $2^{\mathrm{a}}$ \\
\hline & 45 & $6^{\mathrm{b}}$ & $2^{\mathrm{b}}$ & $0^{\mathrm{b}}$ \\
\hline & 55 & $2^{c}$ & $0^{\mathrm{c}}$ & $0^{\mathrm{b}}$ \\
\hline & 65 & $0^{\mathrm{d}}$ & $0^{c}$ & $0^{\mathrm{b}}$ \\
\hline \multirow{5}{*}{ Dicamba } & 20 & $12^{\mathrm{b}}$ & $3^{b c}$ & $0^{\mathrm{b}}$ \\
\hline & 35 & $17^{\mathrm{a}}$ & $7^{\mathrm{a}}$ & $2^{\mathrm{a}}$ \\
\hline & 45 & $10^{\mathrm{b}}$ & $4^{\mathrm{b}}$ & $2^{\mathrm{a}}$ \\
\hline & 55 & $6^{c}$ & $2^{\mathrm{cd}}$ & $1^{\mathrm{ab}}$ \\
\hline & 65 & $3^{c}$ & $1^{\mathrm{d}}$ & $0^{\mathrm{b}}$ \\
\hline
\end{tabular}

${ }^{1}$ Means within a column followed by the same letters are not different according to Fisher's protected LSD test at $P \leq 0.05$.

${ }^{2}$ DAA, days after application.

harvest for 2,4-D applied at 100 or $220 \mathrm{~g}$ ae ha ${ }^{-1}$. Dicamba at $280 \mathrm{~g} \mathrm{ae} \mathrm{ha}^{-1}$ or $2,4-\mathrm{D}$ at $330 \mathrm{~g} \mathrm{ae} \mathrm{ha}^{-1}$ caused 15 to $25 \%$ lodging when applied on sorghum taller than $35 \mathrm{~cm}$. Persistence of lodging for dicamba or the highest rate of 2,4-D applied beyond $55 \mathrm{~cm}$ tall sorghum was noted up to harvest with 6 to $13 \%$ lodging compared to $2 \%$ when application was made on $20 \mathrm{~cm}$ tall sorghum.

Dan et al. [11] reported an increased percentage of lodged plants when 2,4-D was applied at a rate exceeding $420 \mathrm{~g} \mathrm{ae} \mathrm{ha}^{-1}$ on grain sorghum plants with at least nine expanded leaves with up to $36 \%$ at $840 \mathrm{~g} \mathrm{ae} \mathrm{ha}^{-1}$ and $50 \%$ at $1608 \mathrm{~g} \mathrm{ae} \mathrm{ha}^{-1}$. In vitro application of 2,4-D has been shown to induce a shortening of sorghum roots accompanied by uncontrolled growth of adventitious roots [7, 21]. Root systems from susceptible species in nutrient solution containing $0.5 \mathrm{ppm} 2,4-\mathrm{D}$ also exhibited increased cellulase activity [22]. Increasing rates of 2,4-D from 280 to $1120 \mathrm{~g}_{\text {ae }} \mathrm{ha}^{-1}$, applied on grain sorghum at the five-leaf stage, caused fasciation of the brace roots and delayed development of the feeder roots without affecting the yield if sufficient moisture was available [23]. As a consequence of the weakened root systems, grain sorghum plants sprayed with 2,4-D are more prone to lodging as observed in our study. Lodging evaluation before 
TABLE 4: Lodging from POST applications of 2,4-D and dicamba as affected by application timing in 2014 at Rocky Mount and Kinston, North Carolina.

\begin{tabular}{|c|c|c|c|c|c|}
\hline \multirow{2}{*}{$\begin{array}{l}\text { Application } \\
\text { timing } \\
\mathrm{cm}\end{array}$} & \multirow{2}{*}{$\begin{array}{l}\text { Herbicide } \\
\text { g ae ha }^{-1}\end{array}$} & \multicolumn{4}{|c|}{ Lodging $^{1,2}$} \\
\hline & & $7 \mathrm{DAA}$ & $21 \mathrm{DAA}$ & $\begin{array}{l}35 \text { DAA } \\
\%\end{array}$ & Harvest \\
\hline \multirow{4}{*}{20} & 2,4-D 100 & $0^{\mathrm{a}}$ & $0^{\mathrm{b}}$ & $2^{c}$ & $1^{\mathrm{a}}$ \\
\hline & 2,4-D 220 & $0^{\mathrm{a}}$ & $3^{\mathrm{ab}}$ & $3^{\mathrm{bc}}$ & $0^{\mathrm{a}}$ \\
\hline & 2,4-D 330 & $1^{\mathrm{a}}$ & $4^{\mathrm{a}}$ & $6^{\mathrm{ab}}$ & $2^{\mathrm{a}}$ \\
\hline & Dicamba & $1^{a}$ & $3^{\mathrm{ab}}$ & $7 \mathrm{a}$ & $2^{\mathrm{a}}$ \\
\hline \multirow{4}{*}{35} & 2,4-D 100 & $0^{\mathrm{b}}$ & $2^{\mathrm{b}}$ & $3^{\mathrm{b}}$ & $2^{\mathrm{a}}$ \\
\hline & 2,4-D 220 & $0^{\mathrm{b}}$ & $3^{\mathrm{ab}}$ & $5^{\mathrm{b}}$ & $1^{\mathrm{a}}$ \\
\hline & 2,4-D 330 & $0^{\mathrm{b}}$ & $6^{\mathrm{a}}$ & $13^{\mathrm{a}}$ & $4^{\mathrm{a}}$ \\
\hline & Dicamba & $2^{\mathrm{a}}$ & $4^{\mathrm{a}}$ & $15^{\mathrm{a}}$ & $3^{\mathrm{a}}$ \\
\hline \multirow{4}{*}{45} & 2,4-D 100 & $0^{\mathrm{b}}$ & $3^{c}$ & $3^{\mathrm{b}}$ & $1^{\mathrm{b}}$ \\
\hline & 2,4-D 220 & $0^{\mathrm{b}}$ & $5^{\mathrm{bc}}$ & $6^{\mathrm{b}}$ & $1^{\mathrm{b}}$ \\
\hline & 2,4-D 330 & $2^{\mathrm{ab}}$ & $6^{\mathrm{ab}}$ & $15^{\mathrm{a}}$ & $6^{\mathrm{a}}$ \\
\hline & Dicamba & $3^{\mathrm{a}}$ & $8^{\mathrm{a}}$ & $17^{\mathrm{a}}$ & $5^{\mathrm{a}}$ \\
\hline \multirow{4}{*}{55} & 2,4-D 100 & $0^{c}$ & $2^{c}$ & $7^{\mathrm{b}}$ & $1^{\mathrm{b}}$ \\
\hline & 2,4-D 220 & $2^{\mathrm{bc}}$ & $4^{c}$ & $10^{\mathrm{b}}$ & $2^{\mathrm{b}}$ \\
\hline & 2,4-D 330 & $4^{\mathrm{ab}}$ & $7^{\mathrm{b}}$ & $21^{\mathrm{a}}$ & $6^{\mathrm{a}}$ \\
\hline & Dicamba & $6^{\mathrm{a}}$ & $13^{\mathrm{a}}$ & $25^{\mathrm{a}}$ & $8^{\mathrm{a}}$ \\
\hline \multirow{4}{*}{65} & 2,4-D 100 & $0^{c}$ & $5^{b}$ & $8^{\mathrm{b}}$ & $2^{c}$ \\
\hline & 2,4-D 220 & $2^{\mathrm{bc}}$ & $5^{\mathrm{b}}$ & $10^{\mathrm{b}}$ & $2^{c}$ \\
\hline & 2,4-D 330 & $5^{\mathrm{ab}}$ & $9^{\mathrm{ab}}$ & $19^{\mathrm{a}}$ & $7^{\mathrm{b}}$ \\
\hline & Dicamba & $6^{\mathrm{a}}$ & $12^{\mathrm{a}}$ & $21^{\mathrm{a}}$ & $13^{\mathrm{a}}$ \\
\hline
\end{tabular}

${ }^{1}$ Means within a column followed by the same letter are not different according to Fisher's protected LSD test at $P \leq 0.05$.

${ }^{2}$ DAA, days after application.

harvest suggests that grain sorghum may partially recover from injury observed earlier in the season. However, greater lodging damages persisted when dicamba or $2,4-\mathrm{D}$ at the highest rate was applied on sorghum taller than $35 \mathrm{~cm}$.

3.2. Crop Height at Boot Stage. Consistent sorghum height increase at boot stage as compared to the weed-free control that did not receive POST application of growth regulating was observed in three of six environments (Table 6). At Rocky Mount and Clayton in 2012 as well as at Kinston in 2014, 2,4-D applied on 35 to $55 \mathrm{~cm}$ tall sorghum caused sorghum height to increase by $9 \%$ on average for a $220 \mathrm{~g} \mathrm{ae} \mathrm{ha}^{-1}$ rate and by $10 \%$ on average for a $330 \mathrm{~g} \mathrm{ae} \mathrm{ha}^{-1}$ rate compared to the control. Sorghum height increased by $8 \%$ at Rocky Mount in 2012 and by $11 \%$ at Kinston in 2014 compared to the control when 2,4-D was applied at $100 \mathrm{~g} \mathrm{ae} \mathrm{ha}^{-1}$ on 45 or $55 \mathrm{~cm}$ tall plants. Regardless of herbicide rates, application of 2,4-D on $65 \mathrm{~cm}$ tall sorghum did not cause plants to grow taller than in the control. Similarly, dicamba applied at $280 \mathrm{~g} \mathrm{ae} \mathrm{ha}^{-1}$ had little or no effect on crop height, only a slight increase by $6 \%$ compared to the control being noted at Rocky Mount in 2012 and Kinston in 2014 when dicamba was applied on 45 or $55 \mathrm{~cm}$ tall sorghum. Other studies have reported nonsignificant decrease in plant height with 2,4-D applied at
TABLE 5: Lodging from POST applications of 2,4-D and dicamba as affected by herbicide rate in 2014 at Rocky Mount and Kinston, North Carolina.

\begin{tabular}{|c|c|c|c|c|c|}
\hline \multirow{2}{*}{$\begin{array}{l}\text { Herbicide } \\
\text { g ae ha }^{-1}\end{array}$} & \multirow{2}{*}{$\begin{array}{c}\text { Application } \\
\text { timing } \\
\mathrm{cm}\end{array}$} & \multicolumn{4}{|c|}{ Lodging $^{1,2}$} \\
\hline & & $7 \mathrm{DAA}$ & $21 \mathrm{DAA}$ & $\begin{array}{l}35 \text { DAA } \\
\%\end{array}$ & Harvest \\
\hline \multirow{5}{*}{ 2,4-D 100} & 20 & $0^{\mathrm{a}}$ & $0^{\mathrm{b}}$ & $2^{\mathrm{b}}$ & $0^{\mathrm{a}}$ \\
\hline & 35 & $0^{\mathrm{a}}$ & $2^{\mathrm{ab}}$ & $3^{\mathrm{b}}$ & $2^{\mathrm{a}}$ \\
\hline & 45 & $0^{\mathrm{a}}$ & $3^{\mathrm{ab}}$ & $3^{\mathrm{b}}$ & $0^{\mathrm{a}}$ \\
\hline & 55 & $0^{\mathrm{a}}$ & $2^{\mathrm{ab}}$ & $7^{\mathrm{a}}$ & $1^{\mathrm{a}}$ \\
\hline & 65 & $0^{\mathrm{a}}$ & $5^{a}$ & $8^{\mathrm{a}}$ & $2^{\mathrm{a}}$ \\
\hline \multirow{5}{*}{$2,4-\mathrm{D} 220$} & 20 & $0^{\mathrm{b}}$ & $3^{\mathrm{a}}$ & $3^{b}$ & $0^{\mathrm{a}}$ \\
\hline & 35 & $0^{\mathrm{b}}$ & $4^{\mathrm{a}}$ & $5^{\mathrm{b}}$ & $1^{\mathrm{a}}$ \\
\hline & 45 & $0^{\mathrm{b}}$ & $5^{\mathrm{a}}$ & $6^{\mathrm{b}}$ & $1^{\mathrm{a}}$ \\
\hline & 55 & $1^{\mathrm{ab}}$ & $4^{\mathrm{a}}$ & $10^{\mathrm{a}}$ & $2^{\mathrm{a}}$ \\
\hline & 65 & $2^{\mathrm{a}}$ & $5^{\mathrm{a}}$ & $10^{\mathrm{a}}$ & $2^{\mathrm{a}}$ \\
\hline \multirow{5}{*}{ 2,4-D 330} & 20 & $1^{c}$ & $4^{\mathrm{b}}$ & $6^{\mathrm{d}}$ & $2^{\mathrm{b}}$ \\
\hline & 35 & $0^{c}$ & $6^{\mathrm{ab}}$ & $13^{c}$ & $4^{\mathrm{ab}}$ \\
\hline & 45 & $2^{\mathrm{bc}}$ & $6^{\mathrm{ab}}$ & $15^{\mathrm{bc}}$ & $6^{\mathrm{a}}$ \\
\hline & 55 & $4^{\mathrm{ab}}$ & $7^{\mathrm{ab}}$ & $21^{\mathrm{a}}$ & $6^{\mathrm{a}}$ \\
\hline & 65 & $5^{\mathrm{a}}$ & $9^{a}$ & $19^{\mathrm{ab}}$ & $7^{\mathrm{a}}$ \\
\hline \multirow{5}{*}{ Dicamba } & 20 & $1^{\mathrm{b}}$ & $3^{c}$ & $7^{\mathrm{d}}$ & $2^{c}$ \\
\hline & 35 & $2^{\mathrm{b}}$ & $4^{c}$ & $15^{\mathrm{c}}$ & $3^{\mathrm{bc}}$ \\
\hline & 45 & $3^{\mathrm{ab}}$ & $8^{\mathrm{b}}$ & $17^{\mathrm{bc}}$ & $5^{\mathrm{bc}}$ \\
\hline & 55 & $6^{a}$ & $13^{\mathrm{a}}$ & $25^{\mathrm{a}}$ & $8^{\mathrm{b}}$ \\
\hline & 65 & $6^{\mathrm{a}}$ & $12^{\mathrm{ab}}$ & $21^{\mathrm{ab}}$ & $13^{\mathrm{a}}$ \\
\hline
\end{tabular}

${ }^{1}$ Means within a column followed by the same letters are not different according to Fisher's protected LSD test at $P \leq 0.05$.

${ }^{2} \mathrm{DAA}$, days after application.

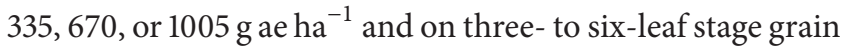
sorghum [12] whereas significant reduction occurred at the same 2,4-D rates on three-leaf stage pearl millet [Pennisetum americanum (L.) Leeke] [24]. These contrasting results may be due to differential sensitivity to $2,4-\mathrm{D}$, which is associated with genetic variations of the different sorghum cultivars.

3.3. Grain Yield at Harvest. As compared to the weedfree control, lower grain yield was noted in four of six environments when dicamba at $280 \mathrm{gaeha}^{-1}$ was applied on 55 and $65 \mathrm{~cm}$ tall sorghum (Table 7). At Clayton and Rocky Mount in 2012 as well as at Kinston and Rocky Mount in 2014, dicamba applied on $55 \mathrm{~cm}$ tall sorghum resulted in significant yield reduction averaging $1.3 \mathrm{Mg} \mathrm{ha}^{-1}$. Similar effect was observed on $65 \mathrm{~cm}$ tall sorghum at Rocky Mount in 2012 and 2013, Clayton in 2012, and Kinston in 2014 with significant yield reduction averaging $1.5 \mathrm{Mg} \mathrm{ha}^{-1}$. Earlier application on 35 or $45 \mathrm{~cm}$ tall sorghum did not cause grain yield loss, except at Clayton in 2012 with reduction by 1.7 and $1.2 \mathrm{Mgha}^{-1}$, respectively. Systematic yield reduction at Clayton in 2012 with dicamba applied at any sorghum growth stage may be due to specific cultivar sensitivity to dicamba as Mycogen1G600 was used for this environment whereas DeKalb DKS 53-67 and Pioneer 84P80 were planted in all 
TABLE 6: Sorghum height at boot stage as affected by growth regulating herbicide rate and application timing in North Carolina ${ }^{1}$.

\begin{tabular}{|c|c|c|c|c|c|c|c|c|}
\hline \multirow{3}{*}{ Herbicide } & \multirow{3}{*}{$\begin{array}{c}\text { Rate } \\
\text { gae ha }^{-1}\end{array}$} & \multirow{3}{*}{$\begin{array}{c}\text { Timing } \\
\mathrm{cm}\end{array}$} & \multicolumn{3}{|c|}{ Rocky Mount } & \multicolumn{2}{|c|}{ Clayton } & \multirow{3}{*}{$\begin{array}{c}\text { Kinston } \\
2014\end{array}$} \\
\hline & & & 2012 & 2013 & 2014 & 2012 & 2013 & \\
\hline & & & \multicolumn{5}{|c|}{$\mathrm{cm}$} & \\
\hline \multirow{3}{*}{$2,4-\mathrm{D}$} & 100 & 35 & $75^{\mathrm{ab}}$ & $101^{\mathrm{a}}$ & $87^{\mathrm{ab}}$ & $58^{\mathrm{b}-\mathrm{d}}$ & $84^{\mathrm{bc}}$ & $86^{e-h}$ \\
\hline & 220 & 35 & $77^{\mathrm{a}}$ & $95^{\mathrm{ab}}$ & $86^{\mathrm{ab}}$ & $59^{\mathrm{bc}}$ & $85^{\mathrm{bc}}$ & $91^{\mathrm{a}-\mathrm{d}}$ \\
\hline & 330 & 35 & $78^{\mathrm{a}}$ & $103^{\mathrm{a}}$ & $85^{\mathrm{ab}}$ & $59^{\mathrm{bc}}$ & $85^{\mathrm{bc}}$ & $91^{\mathrm{a}-\mathrm{d}}$ \\
\hline Dicamba & 280 & 35 & $70^{\mathrm{b}}$ & $88^{\mathrm{b}}$ & $89^{\mathrm{a}}$ & $58^{\mathrm{b}-\mathrm{d}}$ & $85^{\mathrm{bc}}$ & $90^{\mathrm{b}-\mathrm{e}}$ \\
\hline \multirow{3}{*}{$2,4-\mathrm{D}$} & 100 & 45 & $76^{\mathrm{a}}$ & $94^{\mathrm{ab}}$ & $83^{\mathrm{b}}$ & $58^{\mathrm{b}-\mathrm{d}}$ & $89^{\mathrm{a}-\mathrm{c}}$ & $95^{\mathrm{a}}$ \\
\hline & 220 & 45 & $78^{\mathrm{a}}$ & $94^{\mathrm{ab}}$ & $84^{\mathrm{b}}$ & $62^{\mathrm{a}-\mathrm{c}}$ & $83^{\mathrm{c}}$ & $93^{\mathrm{ab}}$ \\
\hline & 330 & 45 & $77^{\mathrm{a}}$ & $101^{\mathrm{a}}$ & $86^{\mathrm{ab}}$ & $63^{\mathrm{a}}$ & $85^{\mathrm{bc}}$ & $93^{\mathrm{ab}}$ \\
\hline Dicamba & 280 & 45 & $78^{\mathrm{a}}$ & $94^{\mathrm{ab}}$ & $87^{\mathrm{ab}}$ & $53^{\mathrm{e}}$ & $85^{\mathrm{bc}}$ & $91^{\mathrm{a}-\mathrm{d}}$ \\
\hline \multirow{3}{*}{$2,4-\mathrm{D}$} & 100 & 55 & $76^{\mathrm{a}}$ & $99^{\mathrm{a}}$ & $86^{\mathrm{ab}}$ & $62^{\mathrm{ab}}$ & $85^{\mathrm{bc}}$ & $91^{\mathrm{a}-\mathrm{d}}$ \\
\hline & 220 & 55 & $78^{\mathrm{a}}$ & $100^{\mathrm{a}}$ & $85^{\mathrm{ab}}$ & $61^{a-c}$ & $93^{\mathrm{ab}}$ & $88^{\mathrm{c}-\mathrm{f}}$ \\
\hline & 330 & 55 & $77^{\mathrm{a}}$ & $104^{\mathrm{a}}$ & $87^{\mathrm{ab}}$ & $59^{\mathrm{a}-\mathrm{d}}$ & $88^{\mathrm{a}-\mathrm{c}}$ & $88^{\mathrm{c}-\mathrm{f}}$ \\
\hline Dicamba & 280 & 55 & $76^{\mathrm{a}}$ & $95^{\mathrm{ab}}$ & $85^{\mathrm{ab}}$ & $57^{\mathrm{c}-\mathrm{e}}$ & $86^{\mathrm{bc}}$ & $88^{\mathrm{c}-\mathrm{f}}$ \\
\hline \multirow{3}{*}{$2,4-\mathrm{D}$} & 100 & 65 & $74^{\mathrm{ab}}$ & $100^{\mathrm{a}}$ & $88^{\mathrm{ab}}$ & $56^{\mathrm{d}-\mathrm{e}}$ & $95^{\mathrm{ab}}$ & $81^{\mathrm{h}}$ \\
\hline & 220 & 65 & $75^{\mathrm{ab}}$ & $96^{\mathrm{ab}}$ & $87^{\mathrm{ab}}$ & $58^{\mathrm{a}-\mathrm{d}}$ & $90^{\mathrm{a}-\mathrm{c}}$ & $83^{\mathrm{gh}}$ \\
\hline & 330 & 65 & $75^{\mathrm{ab}}$ & $102^{\mathrm{a}}$ & $86^{\mathrm{ab}}$ & $57^{\mathrm{c}-\mathrm{e}}$ & $93^{a-c}$ & $86^{\mathrm{e}-\mathrm{h}}$ \\
\hline \multirow[t]{2}{*}{ Dicamba } & 280 & 65 & $74^{\mathrm{ab}}$ & $95^{\mathrm{ab}}$ & $86^{\mathrm{ab}}$ & $57^{\mathrm{b}-\mathrm{e}}$ & $97^{\mathrm{a}}$ & $83^{\mathrm{gh}}$ \\
\hline & Weed-free & & $71^{b}$ & $101^{\mathrm{a}}$ & $85^{\mathrm{ab}}$ & $55^{\mathrm{de}}$ & $86^{\mathrm{a}-\mathrm{c}}$ & $83^{\mathrm{gh}}$ \\
\hline
\end{tabular}

${ }^{1}$ Means within a column followed by the same letters are not different according to Fisher's protected LSD test at $P \leq 0.05$.

TABLE 7: Grain yield as affected by growth regulating herbicide rate and application timing in North Carolina ${ }^{1}$.

\begin{tabular}{|c|c|c|c|c|c|c|c|c|}
\hline \multirow{3}{*}{ Herbicide } & \multirow{3}{*}{$\begin{array}{c}\text { Rate } \\
\text { g ae ha }^{-1}\end{array}$} & \multirow{3}{*}{$\begin{array}{c}\text { Timing } \\
\mathrm{cm}\end{array}$} & \multicolumn{3}{|c|}{ Rocky mount } & \multicolumn{2}{|c|}{ Clayton } & \multirow{3}{*}{$\begin{array}{c}\text { Kinston } \\
2014\end{array}$} \\
\hline & & & 2012 & 2013 & 2014 & 2012 & 2013 & \\
\hline & & & \multicolumn{5}{|c|}{$\mathrm{Mg} \mathrm{ha}^{-1}$} & \\
\hline \multirow{3}{*}{$2,4-\mathrm{D}$} & 100 & 35 & $8.0^{\mathrm{a}-\mathrm{c}}$ & $4.5^{\mathrm{a}-\mathrm{c}}$ & $6.6^{\mathrm{a}}$ & $2.2^{\mathrm{a}-\mathrm{c}}$ & $1.5^{\mathrm{ab}}$ & $5.4^{\mathrm{ab}}$ \\
\hline & 220 & 35 & $8.5^{\mathrm{a}}$ & $4.2^{\mathrm{bc}}$ & $6.0^{\mathrm{a}-\mathrm{c}}$ & $2.4^{\mathrm{ab}}$ & $1.6^{\mathrm{a}}$ & $6.1^{\mathrm{a}}$ \\
\hline & 330 & 35 & $7.7^{\mathrm{b}-\mathrm{d}}$ & $5.2^{\mathrm{ab}}$ & $6.2^{\mathrm{ab}}$ & $2.6^{\mathrm{a}}$ & $1.3^{\mathrm{ab}}$ & $6.1^{\mathrm{a}}$ \\
\hline Dicamba & 280 & 35 & $8.4^{\mathrm{ab}}$ & $4.3^{\mathrm{a}-\mathrm{c}}$ & $6.4^{\mathrm{ab}}$ & $0.6^{\mathrm{fg}}$ & $1.0^{\mathrm{a}-\mathrm{c}}$ & $5.7^{\mathrm{ab}}$ \\
\hline \multirow{3}{*}{$2,4-\mathrm{D}$} & 100 & 45 & $8.0^{\mathrm{a}-\mathrm{c}}$ & $4.5^{\mathrm{a}-\mathrm{c}}$ & $4.4^{\mathrm{c}-\mathrm{e}}$ & $2.3^{\mathrm{ab}}$ & $1.2^{\mathrm{ab}}$ & $6.0^{\mathrm{a}}$ \\
\hline & 220 & 45 & $8.1^{\mathrm{ab}}$ & $4.5^{\mathrm{a}-\mathrm{c}}$ & $3.6^{\mathrm{e}}$ & $2.2^{\mathrm{ab}}$ & $1.0^{\mathrm{a}-\mathrm{c}}$ & $5.6^{\mathrm{ab}}$ \\
\hline & 330 & 45 & $8.3^{\mathrm{ab}}$ & $5.5^{\mathrm{a}}$ & $5.5^{\mathrm{b}-\mathrm{d}}$ & $2.4^{\mathrm{ab}}$ & $1.5^{\mathrm{ab}}$ & $4.4^{\mathrm{cd}}$ \\
\hline Dicamba & 280 & 45 & $8.3^{\mathrm{ab}}$ & $4.5^{\mathrm{a}-\mathrm{c}}$ & $4.6^{\mathrm{c}-\mathrm{e}}$ & $1.1^{\mathrm{d}-\mathrm{f}}$ & $1.5^{\mathrm{a}}$ & $4.5^{\mathrm{b}-\mathrm{d}}$ \\
\hline \multirow{3}{*}{$2,4-\mathrm{D}$} & 100 & 55 & $7.9^{\mathrm{a}-\mathrm{c}}$ & $5.1^{\mathrm{ab}}$ & $4.3^{\mathrm{de}}$ & $2.0^{\mathrm{a}-\mathrm{c}}$ & $1.1^{\mathrm{a}-\mathrm{c}}$ & $5.1^{\mathrm{a}-\mathrm{c}}$ \\
\hline & 220 & 55 & $7.9^{a-c}$ & $4.7^{\mathrm{a}-\mathrm{c}}$ & $5.1^{\mathrm{b}-\mathrm{e}}$ & $1.8^{\mathrm{b}-\mathrm{d}}$ & $0.4^{\mathrm{c}}$ & $5.1^{\mathrm{a}-\mathrm{c}}$ \\
\hline & 330 & 55 & $7.8^{\mathrm{b}-\mathrm{d}}$ & $5.2^{\mathrm{ab}}$ & $5.0^{\mathrm{b}-\mathrm{e}}$ & $2.1^{\mathrm{a}-\mathrm{c}}$ & $0.6^{b c}$ & $5.0^{\mathrm{a}-\mathrm{c}}$ \\
\hline Dicamba & 280 & 55 & $7.3^{\mathrm{cd}}$ & $4.2^{\mathrm{a}-\mathrm{c}}$ & $3.6^{\mathrm{e}}$ & $0.2^{\mathrm{a}}$ & $1.4^{\mathrm{ab}}$ & $4.7^{\mathrm{bc}}$ \\
\hline \multirow{3}{*}{$2,4-\mathrm{D}$} & 100 & 65 & $7.3^{\mathrm{cd}}$ & $4.2^{\mathrm{bc}}$ & $5.7^{\mathrm{a}-\mathrm{d}}$ & $2.2^{\mathrm{ab}}$ & $1.3^{\mathrm{ab}}$ & $5.1^{\mathrm{a}-\mathrm{c}}$ \\
\hline & 220 & 65 & $7.6^{\mathrm{b}-\mathrm{d}}$ & $4.5^{\mathrm{a}-\mathrm{c}}$ & $4.4^{\mathrm{c}-\mathrm{e}}$ & $1.5^{\mathrm{c}-\mathrm{e}}$ & $0.7^{b c}$ & $5.0^{\mathrm{a}-\mathrm{c}}$ \\
\hline & 330 & 65 & $7.6^{b-d}$ & $4.6^{\mathrm{a}-\mathrm{c}}$ & $4.4^{\mathrm{c}-\mathrm{e}}$ & $1.9^{\mathrm{a}-\mathrm{c}}$ & $1.0^{\mathrm{a}-\mathrm{c}}$ & $4.3^{\mathrm{cd}}$ \\
\hline \multirow[t]{2}{*}{ Dicamba } & 280 & 65 & $7.0^{\mathrm{d}}$ & $3.5^{\mathrm{c}}$ & $5.4^{\mathrm{a}-\mathrm{d}}$ & $0.9^{\mathrm{e}-\mathrm{g}}$ & $1.4^{\mathrm{ab}}$ & $3.5^{\mathrm{d}}$ \\
\hline & Weed-free & & $8.2^{\mathrm{ab}}$ & $4.9^{\mathrm{ab}}$ & $4.8^{\mathrm{b}-\mathrm{e}}$ & $2.3^{\mathrm{ab}}$ & $1.3^{\mathrm{ab}}$ & $5.8^{\mathrm{ab}}$ \\
\hline
\end{tabular}

\footnotetext{
${ }^{1}$ Means within a column followed by the same letters are not different according to Fisher's protected LSD test at $P \leq 0.05$.
} 


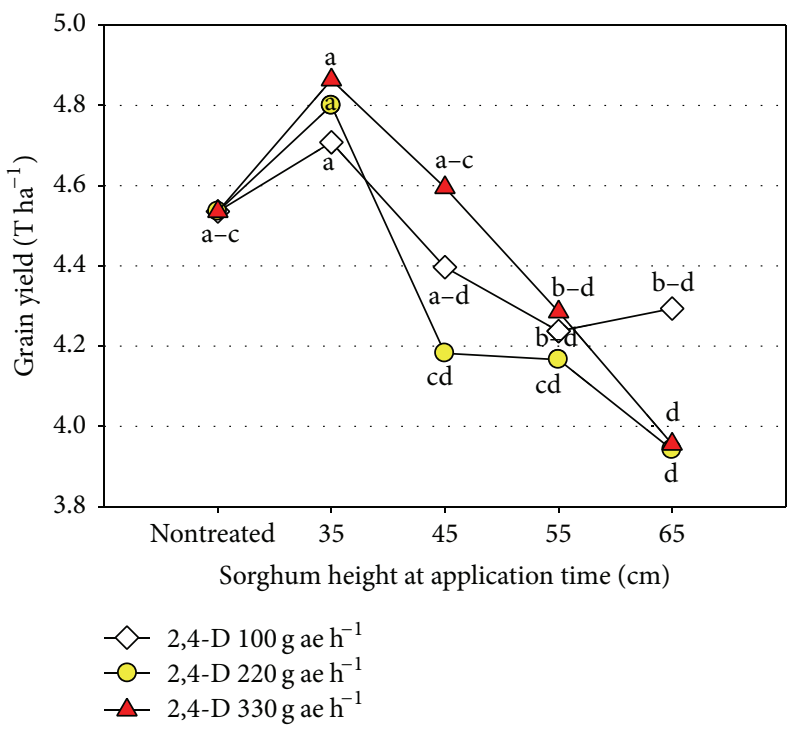

FIGURE 1: Effect of sorghum height at application time on grain yield for three rates of 2,4-D in North Carolina. Data were pooled over environments and means followed by the same letters are not different according to Fisher's protected LSD test $(P \leq 0.05)$.

the other environments. If cultivar sensitivity has not been reported for sorghum, previous studies have shown dicamba injury on sensitive wheat varieties [15, 25]. Rinella et al. [26] have shown that dicamba applied at 140 of $280 \mathrm{~g}$ ae ha ${ }^{-1}$ on F2 to F10 "Wakefield" winter wheat cultivar caused 30 to $100 \%$ underdeveloped seeds that were too small to be harvested. Awad et al. [27] have indicated that there was rapid and extensive metabolism of absorbed dicamba by sorghum with $32 \%$ of the ${ }^{14} \mathrm{C}$ in shoots above treated leaves being metabolized by sorghum 7 days after treatment. Therefore, it is possible that Mycogen1G600 does not metabolize dicamba as rapidly as other cultivars, and underdeveloped seeds may result from herbicide remaining in the plant at the time of gamete formation, anthesis, and seed growth and development.

In the absence of environment-by-treatment interaction after dicamba was removed from the ANOVA analysis, yield data were pooled over environments and are presented in Figure 1. 2,4-D applied at 100, 220, or $330 \mathrm{~g}$ ae ha ${ }^{-1}$ on $35 \mathrm{~cm}$ tall sorghum did not cause significant yield reduction compared to the control. Regardless of herbicide rate, grain yield was not statistically different from the control when 2,4-D application occurred on 45 or $55 \mathrm{~cm}$ tall sorghum. However, compared to the average yield for 2,4-D applied on $35 \mathrm{~cm}$ tall sorghum, significant reduction by $12 \%$ was noted with 2,4-D at $220 \mathrm{~g} \mathrm{ae} \mathrm{ha}^{-1}$ applied at $45 \mathrm{~cm}$ or at any rate when applied on $55 \mathrm{~cm}$ tall sorghum. At the latest stage of application $(65 \mathrm{~cm}), 2,4-\mathrm{D}$ at $100 \mathrm{~g} \mathrm{ae} \mathrm{ha}^{-1} \mathrm{did}$ not significantly reduce yield compared to the control but decreased it by $10 \%$ compared to the average yield for 2,4$\mathrm{D}$ applied on $35 \mathrm{~cm}$ tall sorghum. Increasing 2,4-D rate to 220 or $330 \mathrm{~g} \mathrm{ae} \mathrm{ha}^{-1}$ at the $65 \mathrm{~cm}$ stage caused significant yield reduction by $13 \%$ compared to the control or by $18 \%$ compared to the average yield for 2,4-D applied on $35 \mathrm{~cm}$ tall sorghum.

Reduction in grain yield ranging from 12 to $16 \%$ was also noted for 2,4-D was applied on V5 or V8 sorghum and at
TABLE 8: Pearson correlation coefficients between crop stunting or lodging and sorghum yield at Rocky Mount and Kinston, North Carolina, in $2014^{1}$.

\begin{tabular}{lccc}
\hline Injury & \multicolumn{3}{c}{ Rating } \\
& $7 \mathrm{DAA}$ & $21 \mathrm{DAA}$ & $35 \mathrm{DAA}$ \\
\hline Stunting & $0.10(P=0.21)$ & $0.03(P=0.73)$ & $-0.01(P=0.88)$ \\
Lodging & $-0.20(P=0.01)$ & $-0.28(P \leq 0.01)$ & $-0.27(P \leq 0.01)$ \\
\hline
\end{tabular}

DAA, days after treatment.

720 or $1080 \mathrm{~g} \mathrm{ae} \mathrm{ha}^{-1}$ [13]. Yield reduction was caused by a decreased number of grains per panicle.

At 21 and $35 \mathrm{DAA}$, there was a statistically significant correlation $(P \leq 0.01)$ between lodging injury and grain yield (Table 8 ). While the associated $R$-values were low, this response suggests that the complete recovery from lodging observed by harvest did not compensate for the negative impact that lodging may have had before sorghum pollination.

\section{Conclusion}

This research demonstrated that POST application of growth regulating herbicides beyond the current recommended sorghum height caused increasing lodging, greater injury resulting from application of 2,4-D at $330 \mathrm{gaeha}^{-1}$ or dicamba at $280 \mathrm{gae} \mathrm{ha}^{-1}$. In any situation, application of dicamba at the current recommended rate of $280 \mathrm{~g} \mathrm{ae} \mathrm{ha}^{-1}$ resulted in higher stunting damage than 2,4-D in the days following application. However, unlike lodging, stunting symptoms were not correlated with yield reduction. Since growth regulating herbicide may also affect sorghum root system, damage occurring before pollination may not be compensated early enough to prevent yield reduction. Regardless of local environmental conditions, 2,4-D which applied up 
to $35 \mathrm{~cm}$ tall sorghum could improve broadleaf weed control in grain sorghum systems without negatively impacting grain yield. Applying 2,4-D on 45 or $55 \mathrm{~cm}$ tall sorghum had similar yield impact at each rate. There was a trend for yields to be somewhat lower, but it was only statistically significant at the $220 \mathrm{~g} \mathrm{ae} \mathrm{ha}^{-1}$ rate. However, application of 2,4-D on $65 \mathrm{~cm}$ tall sorghum systematically resulted in significant lower yields. More caution should be taken with dicamba applied at $280 \mathrm{~g}_{\text {ae }} \mathrm{ha}^{-1}$ since yield reduction has been reported as early as applications made on $35 \mathrm{~cm}$ tall sorghum for a sorghum cultivar potentially sensitive to dicamba. Further research should be conducted to address potential differences in sensitivity to dicamba and 2,4-D among sorghum cultivars that are currently commercially available. With regard to the negative impact of dicamba applied over-the-top on sorghum yield observed in our study, concerns may arise from the recent introduction of dicamba-resistant cotton or soybean that could result in off-target movement of dicamba and potentially increase lodging and reduce yield in neighboring sorghum fields. Therefore, investigations should also be directed to evaluate the effects of dicamba or 2,4-D drift on grain sorghum development and commercial yield.

\section{Nomenclature}

2,4-D: Dicamba

Sorghum: Sorghum bicolor (L.) Moench.

\section{Competing Interests}

The authors declare that there are no competing interests regarding the publication of this paper.

\section{References}

[1] North Carolina Department of Agriculture and Consumer Services, Grain Sorghum Fills a Niche in North Carolina, 2013, http://www.ncagr.gov/paffairs/release/2012/11-12sorghum.htm.

[2] P. W. Stahlman and G. A. Wicks, "Weeds and their control in grain sorghum," in Sorghum: Origin, History, Technology, and Production, C. W. Smith and R. A. Frederiksen, Eds., pp. 535590, John Wiley \& Sons, New York, NY, USA, 2000.

[3] W. J. Everman and T. E. Besançon, Grain Sorghum (Milo) Rotation Considerations, 2012, http://carteret.ces.ncsu.edu/.

[4] A. F. Wiese, J. J. Bond, and T. J. Army, "Chemical fallow in the southern Great Plains," Weeds, vol. 8, no. 2, pp. 284-290, 1960.

[5] J. K. Norsworthy, S. M. Ward, D. R. Shaw et al., "Reducing the risks of herbicide resistance: best management practices and recommendations," Weed Science, vol. 60, no. 1, pp. 31-62, 2012.

[6] C. R. Thompson, D. E. Peterson, W. H. Fick, P. W. Stahlman, and J. W. Slocombe, Chemical Weed Control for Field Crops, Pastures, Rangeland, and Noncropland, Kansas State University, Manhattan, Kan, USA, 2015.

[7] S. Bhaskaran and R. H. Smith, "Control of morphogenesis in sorghum by 2,4-dichlorophenoxyacetic acid and cytokinins," Annals of Botany, vol. 64, no. 2, pp. 217-224, 1989.

[8] G. H. L. Liang, K. C. Feltner, and O. G. Russ, "Meiotic and morphological response of grain sorghum to atrazine, 2,4-D, oil and their combinations," Weed Science, vol. 17, no. 1, pp. 8-12, 1969.
[9] O. C. Burnside and G. A. Wicks, "Competitiveness and herbicide tolerance of sorghum hybrids," Weed Science, vol. 20, pp. 314-316, 1972.

[10] W. M. Phillips, Weed Control in Sorghums, Kansas Agricultural Experiment Station, Manhattan, Kan, USA, 1960.

[11] H. A. Dan, L. G. M. Dan, A. L. L. Barroso, J. Oliveira, N. Guerra, and C. Feldkircher, "Tolerance of grain sorghum to 2,4D applied in post-emergence," Planta Daninha, vol. 28, no. 4, pp. 785-792, 2010.

[12] F. A. Petter, L. P. Pacheco, F. Alcântara Neto, A. M. Zuffo, S. O. Procópio, and F. A. Almeida, "Agronomic performance of sorghum as a response to 2,4-D application dosage and times," Planta Daninha, vol. 29, pp. 1091-1098, 2011.

[13] E. Rosales-Robles, R. Sánchez-de-la-Cruz, and L. A. Rodríguezdel-Bosque, "Tolerance of grain sorghum to two herbicides," Revista Fitotecnia Mexicana, vol. 37, no. 1, pp. 89-94, 2014.

[14] E. Rosales-Robles, R. Sánchez-de la Cruz, and P. A. Cerda-García, "Chemical control of broadleaf weeds in grain sorghum," Revista Fitotecnia Mexicana, vol. 34, no. 4, pp. 269-275, 2012.

[15] J. Schroeder and P. A. Banks, "Soft red winter wheat (Triticum aestivum) response to dicamba and dicamba plus 2,4-D," Weed Technology, vol. 3, no. 1, pp. 67-71, 1989.

[16] E. E. Schweizer, J. F. Swink, and P. E. Heikes, "Field bindweed (Convolvulus arvensis) control in corn (Zea mays) and sorghum (Sorghum bicolor) with dicamba and 2,4-D," Weed Science, vol. 26, no. 6, pp. 665-668, 1978.

[17] S. R. Walker, V. A. Osten, D. W. Lack, and L. Broom, "The responses of sorghum and sunflowers to 2,4-D and dicamba residues in clay soils in central Queensland," Australian Journal of Experimental Agriculture, vol. 32, no. 2, pp. 183-187, 1992.

[18] Weedar ${ }^{\circledR} 64$ Herbicide Label, 2015, http://www.cdms.net/ldat/ ld08K001.pdf.

[19] Clarity ${ }^{\circledR}$ Herbicide Label, 2015, http://www.cdms.net/ldat/ ld797012.pdf.

[20] A. Grafen and R. Hails, Eds., Modern Statistics for the Life Sciences, Oxford University Press, New York, NY, USA, 2002.

[21] V. J. Masteller and D. J. Holden, "The growth of and organ formation from callus tissue of sorghum," Plant Physiology, vol. 45 , no. 3, pp. 362-364, 1970.

[22] H. D. Coble and F. W. Slife, "Root dysfunction in honeyvine milkweed caused by 2,4-D," Weed Science, vol. 19, pp. 1-3, 1971.

[23] W. M. Phillips, “The effect of 2,4-D on the yield of midland grain sorghum," Weeds, vol. 6, no. 3, pp. 271-280, 1958.

[24] L. P. Pacheco, F. A. Petter, A. C. F. Câmara et al., "Pennisetum americanum tolerance to 2,4-D," Planta Daninha, vol. 25, no. 1, pp. 173-179, 2007.

[25] P. H. Sikkema, C. Shropshire, and N. Soltani, "Responses of winter wheat (Triticum aestivum L.) to autumn applied postemergence herbicides," Crop Protection, vol. 25, no. 4, pp. 346349, 2006.

[26] M. J. Rinella, J. J. Kells, and R. W. Ward, "Response of 'Wakefield' winter wheat (Triticum aestivum) to dicamba," Weed Technology, vol. 15, no. 3, pp. 523-529, 2001.

[27] A. Awad, A. D. Worsham, F. T. Corbin, and R. Eplee, "Absorption, translocation and metabolism of foliary applied $14 \mathrm{C}$ dicamba in sorghum (Sorghum bicolor) and corn (Zea mays) parasitized with witchweed (Striga asiatica)," in Proceedings of the 5th International Symposium of Parasitic Weeds, pp. 535-536, CIMMYT, Nairobi, Kenya, June 1991. 


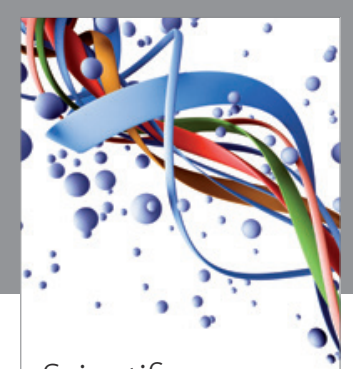

Scientifica
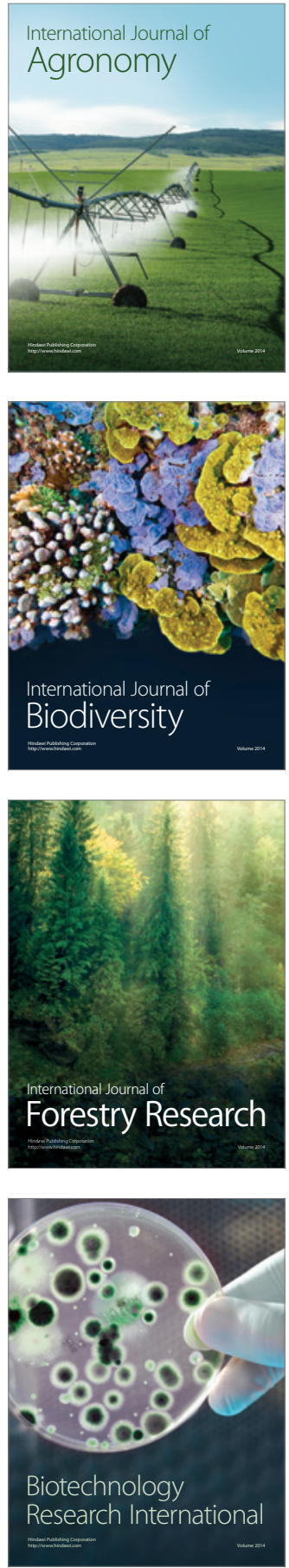
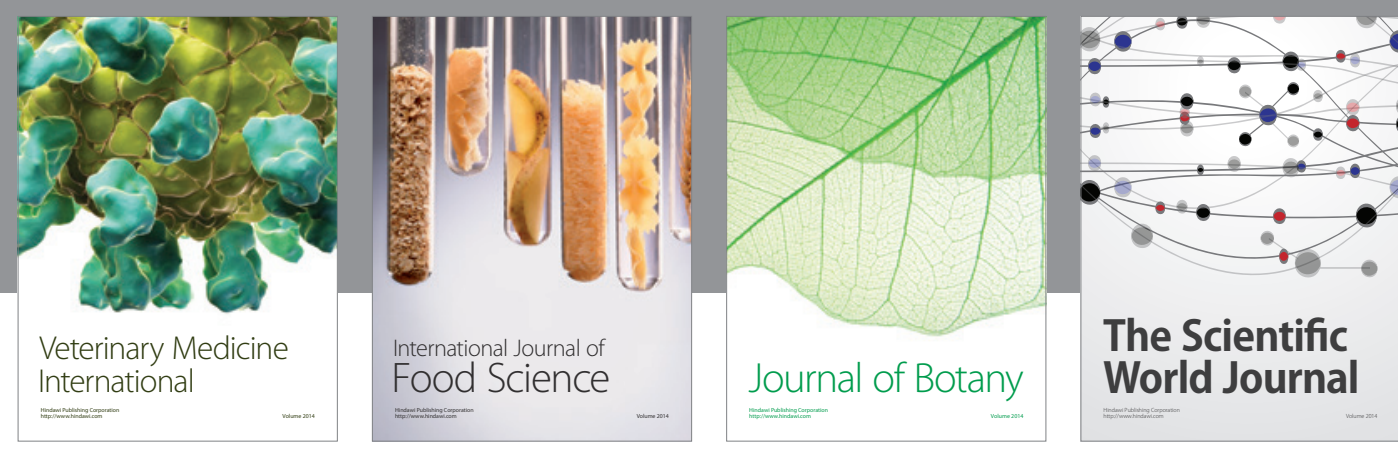

The Scientific

\section{World Journal}

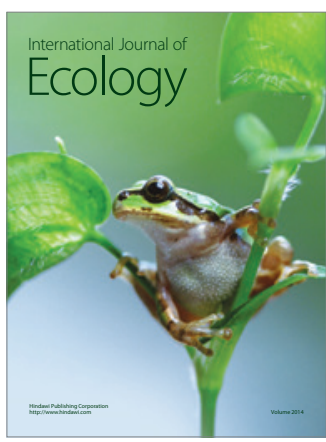

\section{Hindawi}

Submit your manuscripts at

http://www.hindawi.com
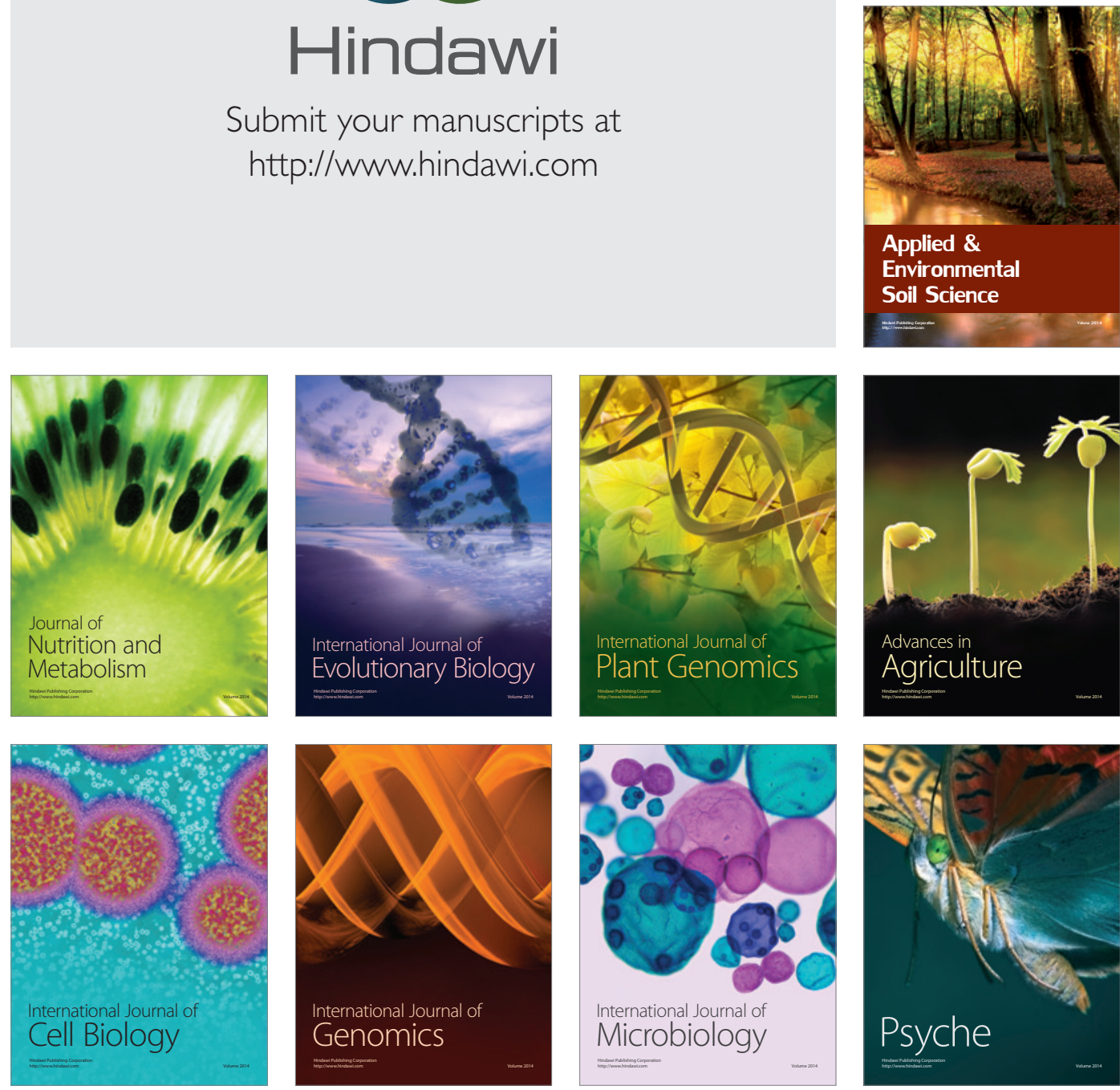
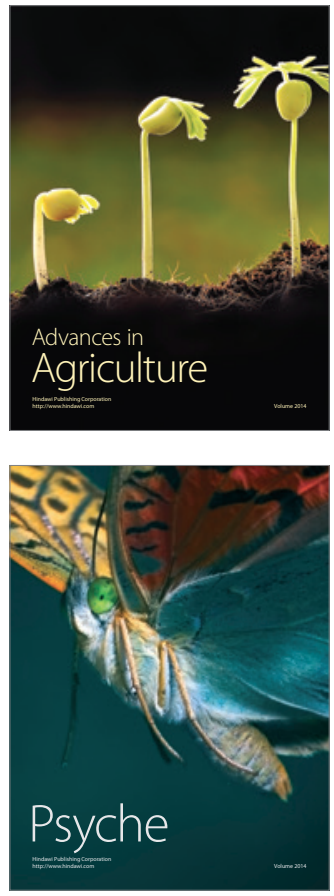